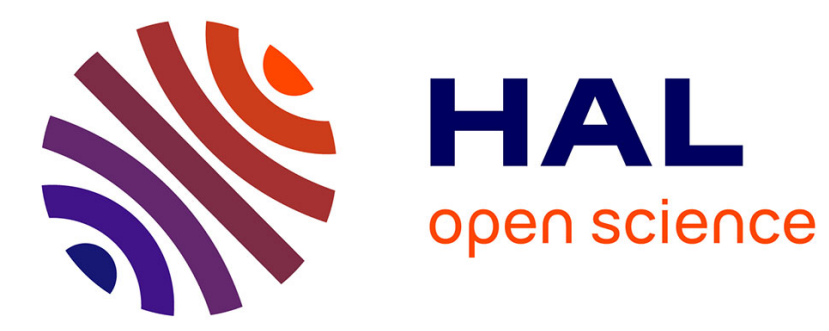

\title{
Dynamics and three-dimensional localization of ribosomal RNA within the nucleolus
}

Marc Thiry, Thierry Cheutin, Marie-Françoise O'Donohue, Hervé H. Kaplan, Dominique Ploton

\section{- To cite this version:}

Marc Thiry, Thierry Cheutin, Marie-Françoise O’Donohue, Hervé H. Kaplan, Dominique Ploton. Dynamics and three-dimensional localization of ribosomal RNA within the nucleolus. RNA, 2000, 6 (12), pp.1750-1761. 10.1017/s1355838200001564 . hal-02328327

\section{HAL Id: hal-02328327 https://hal.science/hal-02328327}

Submitted on 31 May 2021

HAL is a multi-disciplinary open access archive for the deposit and dissemination of scientific research documents, whether they are published or not. The documents may come from teaching and research institutions in France or abroad, or from public or private research centers.
L'archive ouverte pluridisciplinaire HAL, est destinée au dépôt et à la diffusion de documents scientifiques de niveau recherche, publiés ou non, émanant des établissements d'enseignement et de recherche français ou étrangers, des laboratoires publics ou privés. 

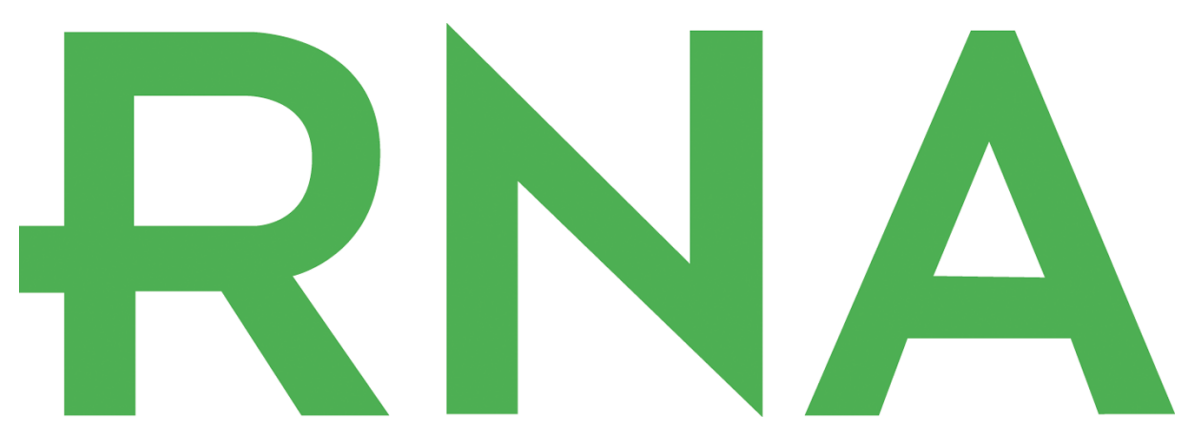

\section{Dynamics and three-dimensional localization of ribosomal RNA within the nucleolus}

M. Thiry, T. Cheutin, M. F. O'Donohue, H. Kaplan and D. Ploton

RNA 2000 6: 1750-1761

$\begin{array}{cl}\text { References } & \begin{array}{c}\text { Article cited in: } \\ \text { http://www.rnajournal.org/cgi/content/abstract/6/12/1750\#-therarticles }\end{array} \\ \begin{array}{c}\text { Email alerting } \\ \text { service }\end{array} & \begin{array}{l}\text { Receive free email alerts when new articles cite this article - sign up in the box at the } \\ \text { top right corner of the article or click here }\end{array} \\ \text { Notes }\end{array}$

To subscribe to RNA go to:

http://www.rnajournal.org/subscriptions/ 


\title{
Dynamics and three-dimensional localization of ribosomal RNA within the nucleolus
}

\author{
MARC THIRY, ${ }^{1}$ THIERRY CHEUTIN, ${ }^{2}$ MARIE-FRANÇOISE O'DONOHUE, ${ }^{2}$ HERVÉ KAPLAN, ${ }^{2}$ \\ and DOMINIQUE PLOTON ${ }^{2}$ \\ ${ }^{1}$ Laboratoire de Biologie Cellulaire et Tissulaire, Université de Liège, 4020 Liège, Belgique \\ ${ }^{2}$ Formation de Recherche en Évolution 2141 Centre National de la Recherche Scientifique, \\ Unité de Formation de Recherche Pharmacie, 51096 Reims Cedex, France
}

\begin{abstract}
Although rRNA synthesis, maturation, and assembly into preribosomal particles occur within the nucleolus, the route taken by pre-rRNAs from their synthetic sites toward the cytoplasm remains largely unexplored. Here, we employed a nondestructive method for the incorporation of BrUTP into the RNA of living cells. By using pulse-chase experiments, three-dimensional image reconstructions of confocal optical sections, and electron microscopy analysis of ultrathin sections, we were able to describe topological and spatial dynamics of rRNAs within the nucleolus. We identified the precise location and the volumic organization of four typical subdomains, in which rRNAs are successively moving towards the nucleolar periphery during their synthesis and processing steps. The incorporation of BrUTP takes place simultaneously within several tiny spheres, centered on the fibrillar centers. Then, the structures containing the newly synthesized RNAs enlarge and appear as compact ringlets disposed around the fibrillar centers. Later, they form hollow spheres surrounding the latter components and begin to fuse together. Finally, these structures widen and form large rings reaching the limits of the nucleoli. These results clearly show that the transport of pre-rRNAs within the nucleolus does not occur randomly, but appears as a radial flow starting from the fibrillar centers that form concentric rings, which finally fuse together as they progress toward the nucleolar periphery.
\end{abstract}

Keywords: BrUTP; nucleolus; ribosomal RNA; ribosome biogenesis; transfection

\section{INTRODUCTION}

Since it became evident that cell nuclei are compartmentalized organelles (Spector, 1993; Strouboulis \& Wolffe, 1996; Singer \& Green, 1997; Lamond \& Earnshaw, 1998), one of the major goals in cell biology has been to understand their functional organization. In particular, the nucleolus provides the fascinating possibility of linking morphologically distinct structures such as those seen in the electron microscope with biochemical features of the synthesis of rRNAs and stepwise maturation of ribosomes.

In eukaryotic cells, the synthesis and maturation of cytoplasmic rRNAs mainly take place in the nucleolus (Hadjiolov, 1985; Sollner-Webb et al., 1996). The 18S, 5.8S, and 25/28S rRNAs are synthesized as simple precursor RNAs (pre-rRNAs), which contain long external and internal transcribed spacers. The primary transcripts are processed through a complex pathway

Reprint requests to: Marc Thiry, Laboratoire de Biologie Cellulaire et Tissulaire, Université de Liège, 20, rue de Pitteurs, 4020 Liège, Belgique; e-mail: mthiry@ulg.ac.be. of endonucleolytic cleavages, exonucleolytic digestions, and covalent modifications. These pre-rRNAs are assembled with ribosomal and nonribosomal proteins in addition to the separately transcribed $5 S$ rRNAs. In this way, the large and small preribosomal particles are formed and subsequently released from the nucleolus into the cytoplasm, where they assembled into fully functional ribosomes.

Using cytological methods, considerable efforts have been devoted to the identification of the nucleolar sites at which the various biochemical events in rRNA synthesis take place. In the mammalian cell nucleolus, three major substructures have been visualized by electron microscopy: the fibrillar center (FC), the dense fibrillar component (DFC), and the granular component (GC) (Thiry \& Goessens, 1996). Most studies dealing with the nucleolus have been focused on the identification of rDNA transcription sites (Shaw \& Jordan, 1995; Thiry \& Goessens, 1996; Scheer \& Hock, 1999). There is a general consensus that transcription occurs in the fibrillar regions of the nucleolus, but whether it is within the DFC, or at the border of the DFC and the FC, or even within the $\mathrm{FC}$, remains a matter of much debate. 
Kinetic information concerning the synthesis and maturation of pre-rRNA molecules within the nucleolus of intact, active cells is equally sparse. Autoradiographic studies (Fakan, 1978) have consistently shown that when rRNAs are labeled with tritiated uridine for short periods of time, the signal is uniquely localized on the fibrillar part of the nucleolus. The GC only becomes labeled after longer periods of radioactive incubation and/or after a cold chase. In complementary biochemical studies (Daskal et al., 1974; Royal \& Simard, 1975), 45S pre-rRNAs appear restricted to the fibrillar component while $32 \mathrm{~S}$ (i.e., pre-28S) rRNAs are also located in the GC. Together, these data suggest a migration of pre-rRNA molecules from the fibrillar component into the GC. However, autoradiography displays a projection onto a plane of the three-dimensional data, thus discarding the possibility of dealing with the question of the spatial organization of the labeling.

In recent years, immunocytological methods have been developed for detecting newly synthesized RNAs within the cell using a BrUTP analog (Jackson et al., 1993; Wansink et al., 1993). These approaches have shown that transcription by RNA polymerase II is organized in discrete foci scattered throughout the nucleoplasm. However, it has proven difficult to visualize the nucleolar transcription sites (Jackson et al., 1993; Wansink et al., 1993; Iborra et al., 1996; Pombo et al., 1999; Wei et al., 1999). Unless special procedures are employed, the nucleolus remains unlabeled despite the high level of transcription within this organelle (Hadjiolov, 1985; Moss \& Stefanovsky, 1995). Labeling of the nucleolus can be achieved by several methods. RNA polymerase II inhibitors such as $\alpha$-amanitin or DRB can be employed or, alternatively, RNA polymerase I-mediated transcription can be stimulated in a variety of ways (Jackson et al., 1993; Wansink et al., 1993; Hozak et al., 1994). For example, $\mathrm{NH}_{4} \mathrm{SO}_{4}$ has been added to the transcription medium (Jackson et al., 1993) and Masson et al. (1996) have reported that by removing glycerol from the permeabilization and transcription buffers and improving permeabilization with Triton X-100, it is possible to reveal RNA polymerase I transcription without the addition of inhibitors. Recently, Koberna et al. (1999) have shown that the use of a hypotonic shift procedure facilitates the uptake of BrUTP into the nucleolus. However, all these experimental conditions perturb the cell integrity and may cause partial degradation of subcellular structures, leading to ultrastructural modifications as reported by some authors (Dundr \& Raska, 1993; Masson et al., 1996). In addition, the nucleolar labeling is always restricted to the synthetic sites and the transport of newly labeled rRNAs either within or from the nucleus to the cytoplasm has not yet been detected.

In the present work, we addressed the following question: What is the volumic organization of sites containing newly synthesized rRNA molecules during their elongation and also during their processing within the nucleolar volume? To answer this point, we used a new method for BrUTP incorporation within optimally preserved cells that allowed us to follow the kinetics of rRNA synthesis and maturation. Our data, obtained with laser scanning confocal microscopy coupled to three-dimensional image reconstructions, electron microscopy, and double labeling with RNA polymerase I and fibrillarin, reveal the volumic organization of rRNAs during the time course of their synthesis and maturation. They demonstrate that BrUTP-labeled rRNAs are initially localized both within the FC and in the inner part of the DFC, then they migrate rapidly within ringlets around the $\mathrm{FC}$ and hollow spheres centered on each FC. Finally, they are present within voluminous rings whose external limits correspond to the periphery of the nucleolus. Both the functional significance and the new insights brought by these results are discussed.

\section{RESULTS}

\section{Immunofluorescence localization of BrUTP-labeled RNAs in intact HeLa cells}

When HeLa cells were lipofected (or pulse-labeled) for 15 min with BrUTP-FuGene-6 complexes and then chased for $15 \mathrm{~min}$ in the culture medium devoid of complexes, a significant proportion of cells $(45 \%, n=$ 4,000 ) exhibited a clear labeling in their nucleoplasm and, to a greater extent, in the nucleoli, as observed both by phase contrast and fluorescence microscopy (Fig. 1A,B). The nucleoplasmic labeling appears as multiple fine dots dispersed in extranucleolar areas of the nuclei, whereas its nucleolar counterpart is formed by a limited number of large spots lying in the nucleolar volume. To determine whether the extranucleolar incorporation of BrUTP was due to RNA polymerase II activity, cells were pretreated with $100 \mu \mathrm{g} \mathrm{mL}^{-1} \alpha$-amanitin, a specific inhibitor of this enzyme (Roeder, 1976). After a 1-h treatment, all the nucleoplasmic dots disappeared and the labeling became exclusively nucleolar or cytoplasmic, as confirmed by phase contrast microscopy (Fig. 1C,D). The nucleolar labeling was similar to that of untreated cells, which clearly demonstrates that the BrUTP incorporation observed in nucleoli is strictly RNA polymerase I dependent. This was further evidenced by the abolition of the nucleolar labeling when cells were pretreated for 30 min with $0.05 \mu \mathrm{g} \mathrm{mL}^{-1}$ actinomycin D, which only inhibited RNA polymerase I activity under these conditions (Fig. 1E,F). Finally, when nonlipofected cells were used, or cells lipofected with FuGene-6 alone or with FuGene-6-UTP (instead of BrUTP), the slides were completely devoid of label. Furthermore, no label was observed when the primary antibody was omitted (results not shown). 


\section{Phase contrast}
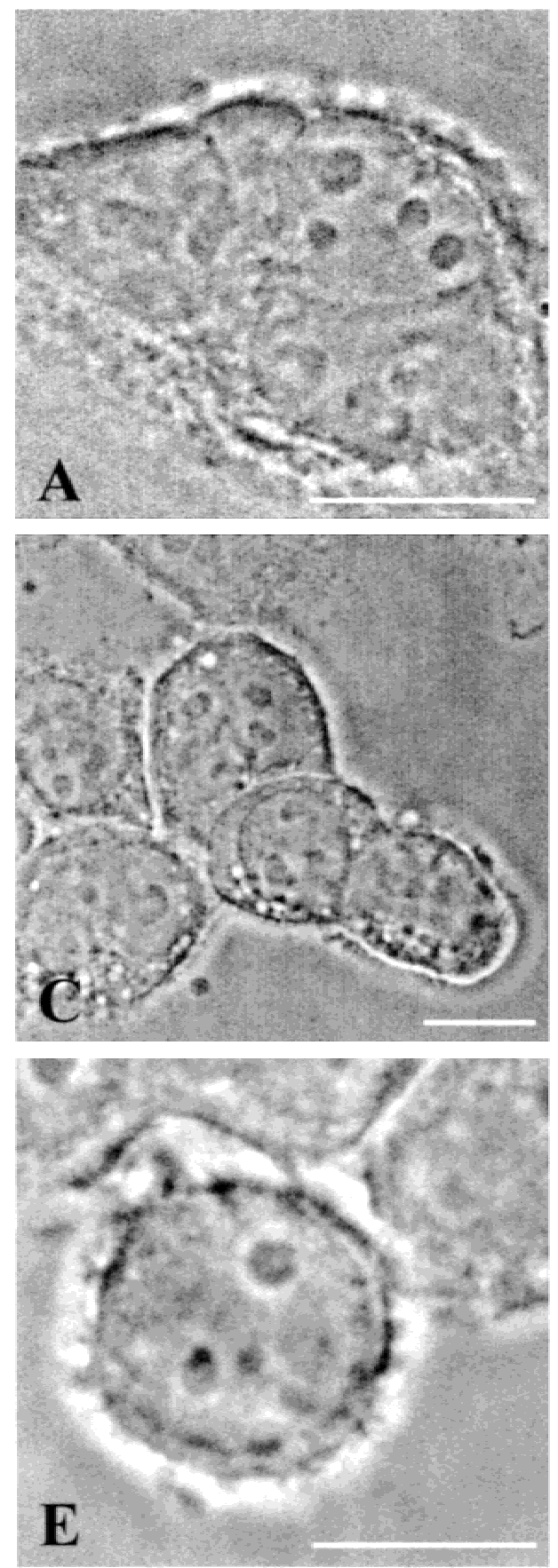
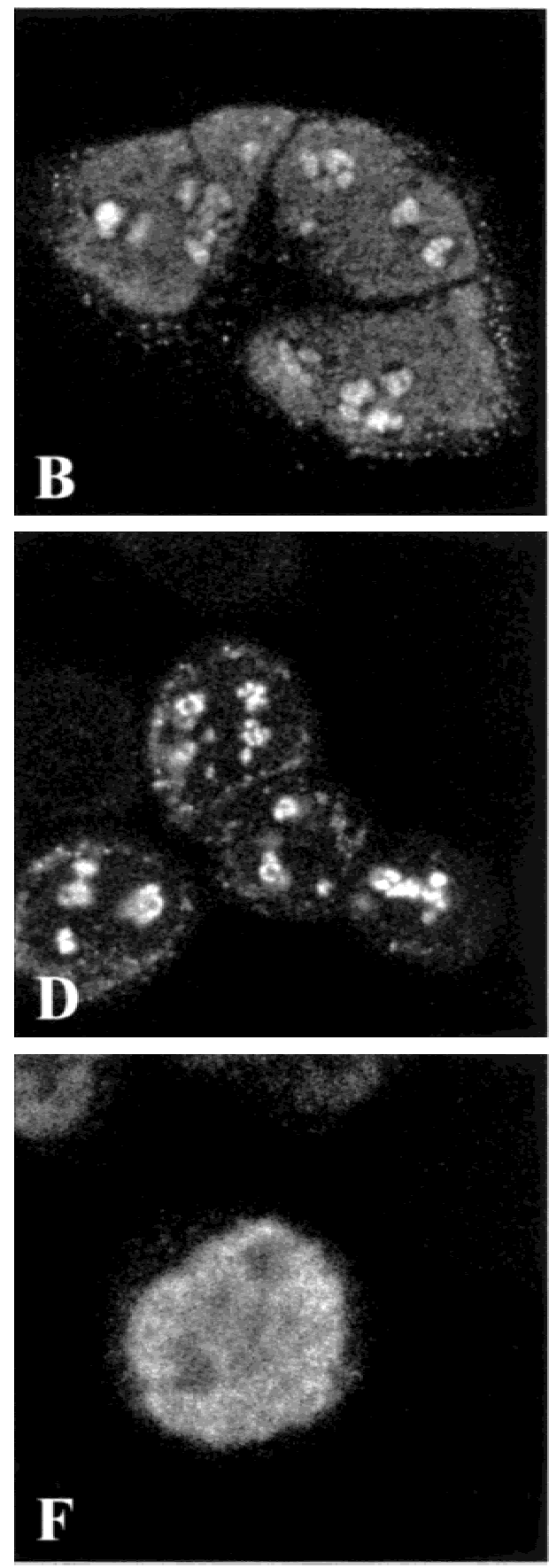

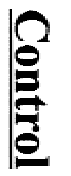

בְּ.

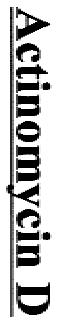

FIGURE 1. Immunofluorescence localization of BrUTP-labeled RNAs in intact HeLa cells. Cells were lipofected for 15 min with BrUTP-FuGene-6 complexes and then cultured for $15 \mathrm{~min}$. Cells were grown without the addition of inhibitors $(\mathbf{A}, \mathbf{B})$ or in presence of either $\alpha$-amanitin (C,D) or actinomycin D (E,F). BrUTP-labeled rRNAs were detected by an indirect immunofluorescence method. A,C,E: Phase contrast images; B,D,F: single optical section of the same fields obtained in confocal microscopy. Bar: $10 \mu \mathrm{m}$.

\section{Evidence for the migration of BrUTP-labeled rRNAs from the nucleolus to the cytoplasm}

To exclusively visualize the rRNA transcripts and their potential movements, lipofected cells were pretreated with $\alpha$-amanitin to abolish extranucleolar transcription.
The labeling obtained after various chase times was analyzed by confocal microscopy (Fig. 2). When the slides were fixed immediately after lipofection, it is noteworthy that very few cells were labeled and that the fluorescence was preferentially found over the nucleoli (data not shown). When the cells were chased for only 
Phase contrast
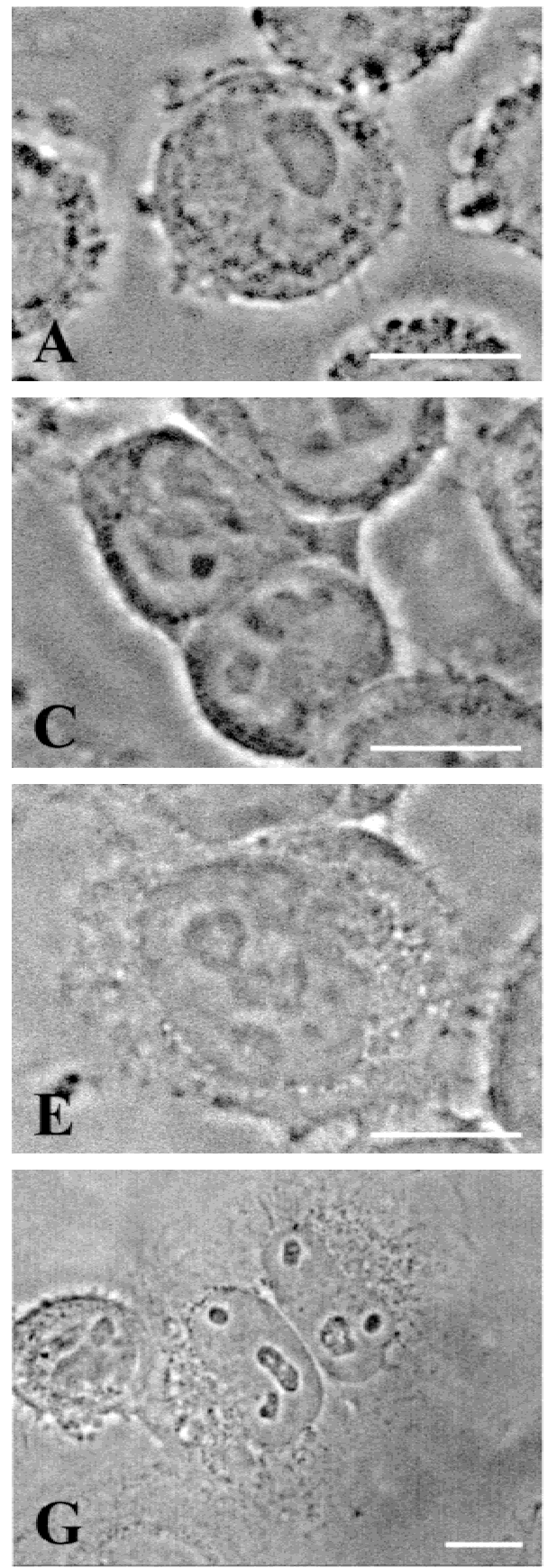

$\underline{\text { BrUTP }}$
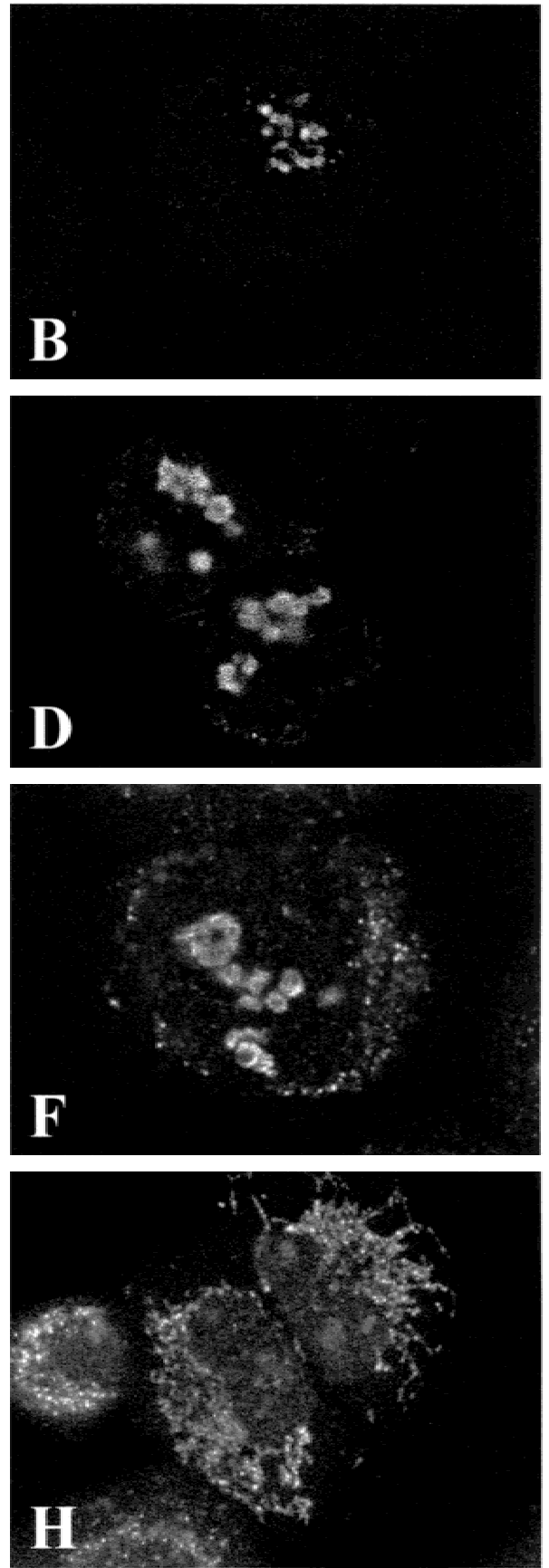

䟿

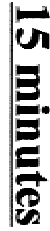

FIGURE 2. Evidence for the migration of BrUTP-labeled rRNAs from the nucleolus to the cytoplasm. $\alpha$-amanitin-treated HeLa cells were lipofected for 15 min with BrUTP-FuGene-6 complexes and then cultured in medium without BrUTP for $2 \mathrm{~min}(\mathbf{A}, \mathbf{B}), 15 \mathrm{~min}(\mathbf{C}, \mathbf{D}), 30 \mathrm{~min}(\mathbf{E}, \mathbf{F})$, and $60 \mathrm{~min}(\mathbf{G}, \mathbf{H})$ before being fixed. BrUTP-labeled rRNAs were detected by an indirect immunofluorescence method. A,C,E,G: Phase contrast images; B,D,F,H: single optical section of the same fields obtained in confocal microscopy. Bar: $10 \mu \mathrm{m}$.

2 min after lipofection with BrUTP (Fig. 2A,B), the nucleolar labeling consists of many tiny spots, which occupy a limited portion of the nucleoli (compare panels $A$ and B, Fig. 2). After a 15-min chase, the labeling appears to have migrated towards the periphery of the nucleoli leaving the center largely unlabeled (Fig. 2C,D).
After $30 \mathrm{~min}$, this tendency is confirmed with the labeling being localized at the extreme limits of the nucleoli, forming fluorescent rims that sometimes contact each other (Fig. 2E,F). After a 15- or 30-min chase, a cytoplasmic labeling progressively appears (Fig. 2D,F). It becomes predominant after a 90 min chase, with in- 
tense, punctuated foci covering the cytoplasm, whereas the nucleolar labeling is extremely faint (Fig. $2 \mathrm{H}$ ). Taken together, these data suggest the passage of the transcripts from their synthesis sites toward the cytoplasm.

\section{Time-dependent migration of BrUTP-rRNAs from RNA polymerase I-positive sites to the periphery of the nucleoli}

Having localized BrUTP incorporation, we attempted to determine whether this incorporation strictly takes place in sites where the rRNA machinery is located and whether the labeled RNA are rapidly excluded from these sites. To perform this study, the spatial distribution of pre-rRNAs (Fig. 3, green) obtained in $\alpha$-amanitintreated cells lipofected with BrUTP for increasing times of chase was compared in individual optical sections to that of RNA polymerase I (Fig. 3, red), a marker of rRNA synthesis sites (Scheer \& Rose, 1984). Similar experiments, conducted in the absence of $\alpha$-amanitin, led to similar results (data not shown).
After short chase periods, BrRNAs (Fig. 3A) and RNA polymerase I (Fig. 3B) display identical patterns in the nucleoli. Superimposition of these two images reveals a systematic colocalization of RNA polymerase I with most of the transcripts, as indicated by the yellow signal in Figure 3C,D. This result indicates that all the sites containing RNA polymerase I are active for RNA synthesis. However, the transcripts occupy a much wider zone around RNA polymerase I, suggesting a rapid migration of the transcripts from their elongation sites. Fifteen to thirty minutes after lipofection, the relative surface of colocalization of the two signals strongly decreases and typically appears as rings positioned around the sites at which RNA polymerase I was located (Fig. $3 \mathrm{H}, \mathrm{L})$. RNA polymerase $\mathrm{I}$ is detected as round spots at the center of the structures, whereas the BrUTP labeling seems to expand around these spots in a centrifugal manner, occupying an increasingly wider territory as the chase time increases. It is striking that the gaps present in the BrUTP labeling correspond to the RNA polymerase I-positive spots (Fig. 3E-G,I-K).
BrUTP
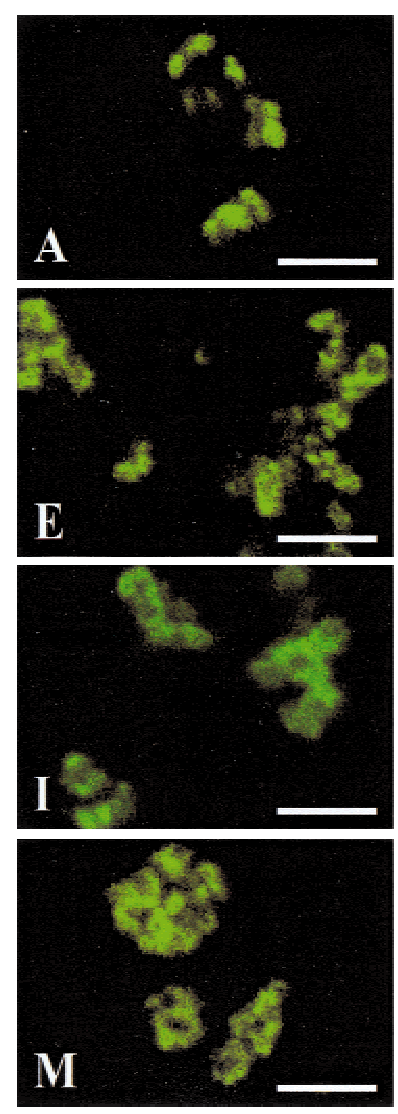

RNA Pol. I
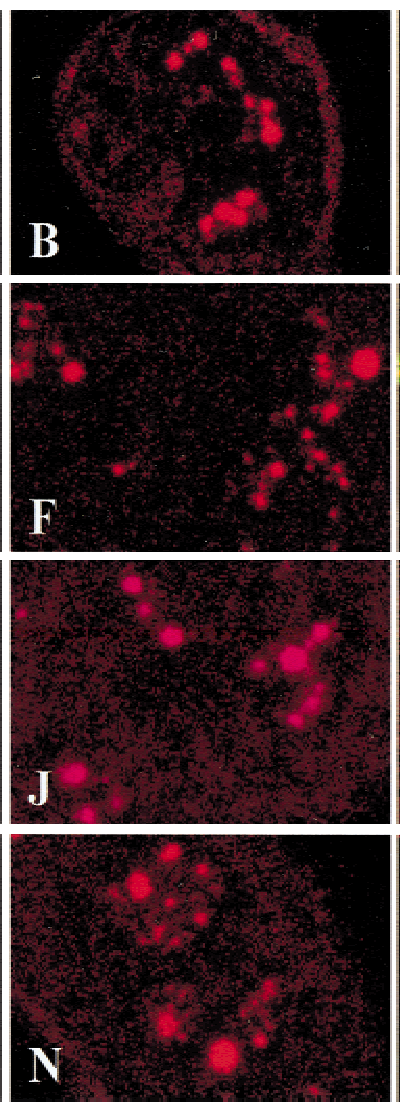
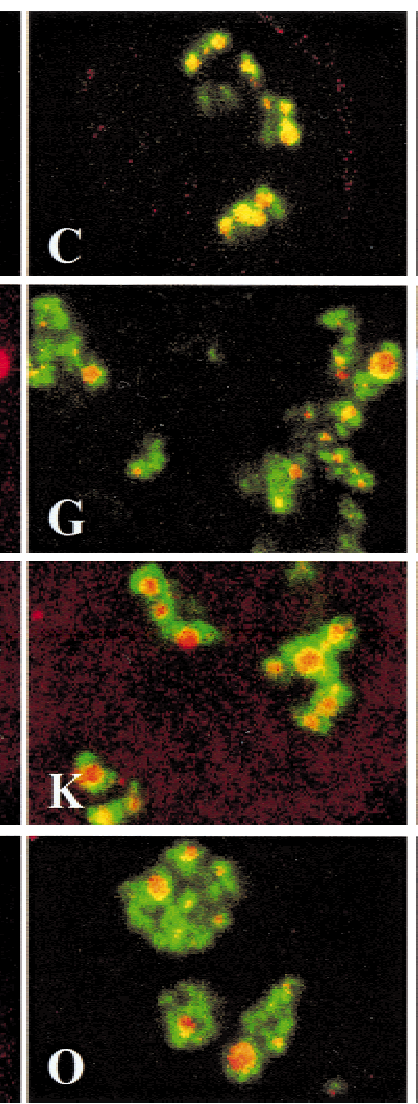

\section{Colocalization}
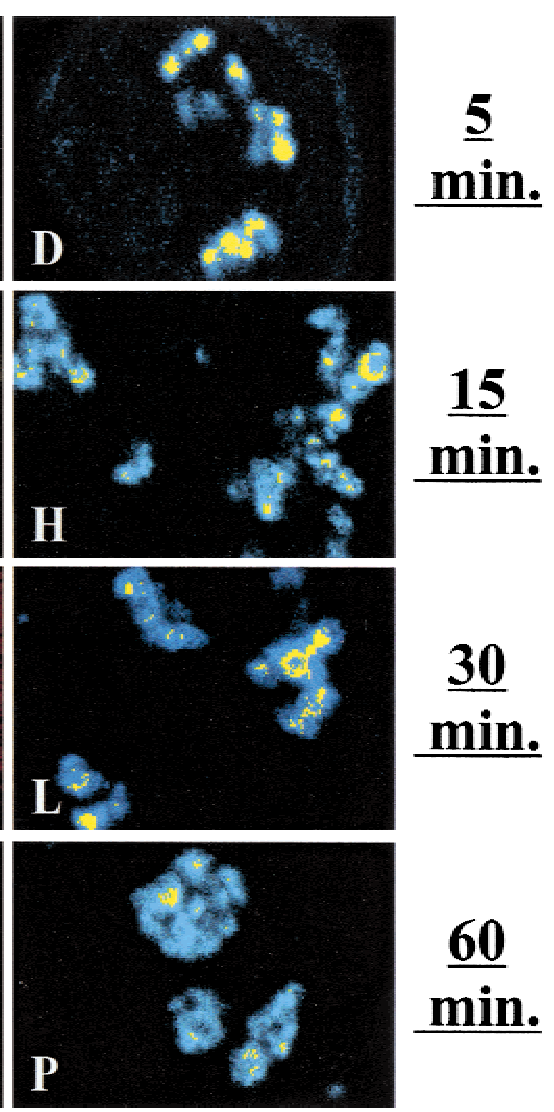

$\underline{60}$

min.

FIGURE 3. Evidence for the time dependent migration of BrUTP-labeled rRNAs from RNA polymerase I rich sites to their periphery. Double immunofluorescence detection of BrUTP-labeled rRNAs (green; A,E,I,M) and RNA polymerase I (red; $\mathbf{B}, \mathbf{F}, \mathbf{J}, \mathbf{N})$ in $\alpha$-amanitin-treated HeLa cells cultured in medium without BrUTP for 5 min $(\mathbf{A}-\mathbf{D}), 15 \mathrm{~min}(\mathbf{E}-\mathbf{H})$, and 30 min (I-P) after lipofection with BrUTP-FuGene-6 complexes. Overlay of green and red signals (C,G,K,O). Colocalization of green and red signals with highest intensity shown in yellow relative to all the labeled sites in blue (D,H,L,P). Bar: $5 \mu \mathrm{m}$. 
Finally, $1 \mathrm{~h}$ after transfection, the colocalization areas become very rare (Fig. 3P).

The spatial distribution of pre-rRNAs obtained in $\alpha$-amanitin-treated cells lipofected with BrUTP for increasing times of chase was also compared in individual optical sections to that of fibrillarin, a marker of the DFC where the majority of the maturation steps occur (Thiry \& Goessens, 1996). The results clearly show that most of the BrUTP signal is colocalized with fibrillarin between 5 and 15 min of chase (data not shown).

\section{Ultrastructural identification of the nucleolar components containing BrUTP-RNAs during their migration within the nucleolus}

To define the fine structural location of rRNA transcripts during their intranucleolar migration, our approach was adapted at the ultrastructural level in absence of $\alpha$-amanitin. Under these conditions, the ultrastructure of the compact HeLa cell nucleolus was very well preserved: the various nucleolar components (FC, DFC, and GC) were easily recognizable (Fig. 4). In particular, the FC were clearly visible, their diameter ranging from 0.4 to $1.2 \mu \mathrm{m}$. The first sites to be labeled are both fibrillar components, i.e., FC and part of DFC (Fig. 4A). Later, the labeling is restricted to the DFC immediately surrounding the FC (Fig. 4B). Afterwards, the gold label is present over extensions of the DFC rims, mainly at a remote distance from the FC (Fig. 4C). Finally, the gold labeling progressively moves into the GC. At this stage, the FC and the DFC are gold-free (Fig. 4D). Control experiments were performed to check the specificity of the labeling. No signal was observed when nonlipofected cells were used, or cells lipofected with FuGene-6 alone or with FuGene-6-UTP (instead of BrUTP). Likewise, no label was seen when the anti-BrdU antibody was omitted from the medium in the immunocytological reaction. Finally, when cells were lipofected with
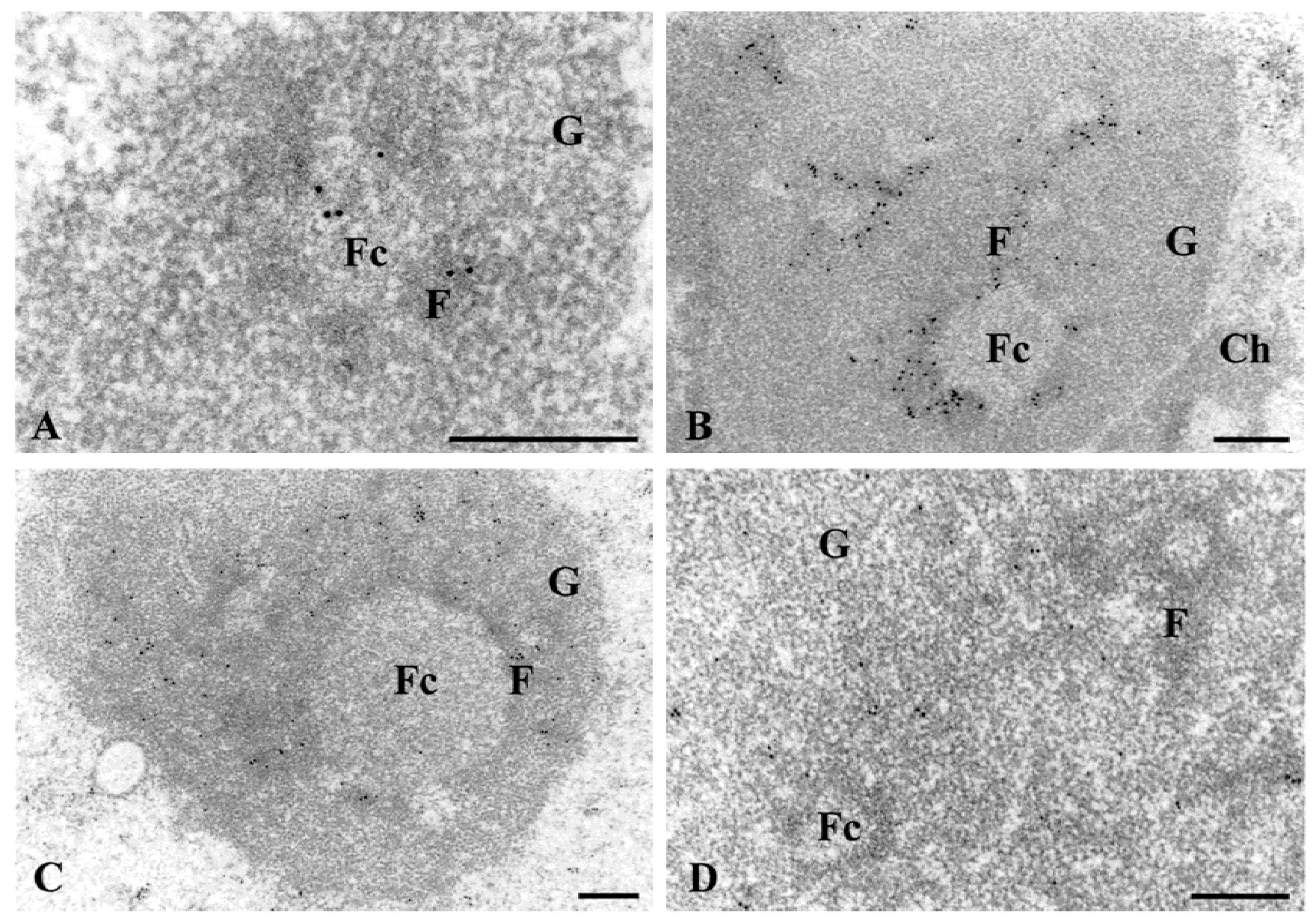

FIGURE 4. Ultrastructural identification of nucleolar components containing the BrRNAs during their movement within the nucleolus. Immunogold labeling detection of BrUTP-labeled rRNAs on ultrathin sections of HeLa cells lipofected with BrUTP-FuGene-6 complexes and then cultured in medium without BrUTP for $10 \mathrm{~min}$ (A), $15 \mathrm{~min}$ (B), and $30 \mathrm{~min}$ (C,D). Cells were grown without the addition of inhibitor. Under these experimental conditions, the three main nucleolar components are clearly identified: The fibrillar centers (Fc), the dense fibrillar component $(F)$ and the granular component $(G)$. Ch: Condensed chromatin. Bars: $0.4 \mu \mathrm{m}$. 
BrdUTP instead of BrUTP, the labeling was exclusively found over DNA-containing structures, such as blocks of condensed chromatin (data not shown).

\section{Three-dimensional structure of nucleolar subdomains containing BrUTP-rRNAs}

To provide data concerning the volumic organization of the sites containing BrUTP-labeled RNAs during their movement from initial sites of transcription to the periphery of the nucleolus, we performed threedimensional image reconstruction. To do this, we used the z-series of confocal optical sections, which allowed us to obtain highly resolved three-dimensional visualizations. Using the same magnification, we examined pre-rRNA localization within the nucleolar volume after various chase times in the absence (data not shown) or in the presence of $\alpha$-amanitin (Fig. 5), either through a single optical section (left panels), or through a threedimensional reconstruction of the whole volume (right panels). For short chase times, the BrUTP labeling appears as multiple fluorescent spots that are often aligned and grouped in clusters (Fig. 5A). The three-dimensional reconstruction (Fig. 5B) shows that these fluorescent spots are individual full beads $0.5 \mu \mathrm{m}$ in diameter (inset), organized as a necklace. After a 15-min chase, these spots have partly fused together as a result of their progressive, centrifugal growth, leading to the generation of large strands (Fig. 5D). However, a closer examination reveals that the global labeling is composed of individual ringlets $0.8 \mu \mathrm{m}$ in diameter, whose centers are devoid of fluorescence. A volumic representation reveals a small central depression (see inset in Fig. 5D) and a smooth surface. After a 30-min chase, the labeling expands within larger rims, assembled in wider and more complex structures, that are the result of the partial fusion of several rims originating from different FCs (Fig. 5E). Each unlabeled part of the rim corresponds to the individual spots previously observed in Figure 5C,D. The three-dimensional organization revealed that the labeling is organized as hollow spheres $1.5 \mu \mathrm{m}$ in diameter, with an irregular surface due to the presence of numerous threadlike structures (Fig. 5F and inset). Finally, after prolonged chase times (1 h), the nucleolar labeling becomes larger and more peripheral (Fig. $5 \mathrm{H})$. A view of an individual optical section demonstrates that it is composed of several very large threads localized at the outer part of the nucleolus (Fig. 5G). Large areas of the labeling display a higher fluorescence intensity, which could correspond to an accumulation of rRNAs at the periphery of the nucleoli. The volumic representation indicates that the labeling is organized as several large rings $3-4 \mu \mathrm{m}$ in diameter, whose surface is homogenous (Fig. 5H). Although some of these rings are complete, others are composed of a succession of peripheral clusters of labeled material, interrupted by gaps. This is consistent with a complete dispersion of the labeling upon chase, leading ultimately to a total disorganization of these structures. It is interesting to note that for any given time point, the nucleolar labeling tended to progress synchronously within all the nucleoli of a single cell.

\section{DISCUSSION}

\section{The approach for identifying both transcription and processing sites in the nucleolus}

This work describes a nonisotopic method for investigating the kinetics of RNAs in cells at light and electron microscopic levels. Surprisingly, previous studies suggest that BrUTP is poorly incorporated into RNA and that the presence of bromine inhibits its transport and/or processing. For instance, microinjection of high concentrations of BrUTP into living cells has been proved to be toxic and prevents transport to the cytoplasm (Fay et al., 1997), and complete substitution of uridine inhibited splicing and translation in vitro (Sierakowska et al., 1989; Schmittgen et al., 1994; Wansink et al., 1994). However, in these previous studies, the introduction of nucleotide analogs was generally achieved by cell membrane permeabilization using Triton X-100 (Dundr \& Raska, 1993; Jackson et al., 1993; Wansink et al., 1993; Hozak et al., 1994; Masson et al., 1996; Melcak et al., 1996) or by microinjection (Wansink et al., 1993; Masson et al., 1996; Cmarko et al., 1999). Consequently, these procedures could greatly affect the cell integrity. Moreover, the permeabilization treatment may cause drastic alteration and partial degradation of subcellular structures. In contrast, it has been shown recently that when cells are exposed for short periods of time to low concentrations of the nucleoside analog $\mathrm{BrU}$, instead of the nucleotide analog BrUTP, they grow normally and the resulting BrRNAs are transported to the cytoplasm (Iborra et al., 1998). However, this labeling only revealed nonnucleolar RNAs.

The approach that we have employed uses natural cellular mechanisms to introduce nucleotide analogs into intact cells. We show that FuGene-6, in addition to functioning as a transfectant for plasmids, efficiently and rapidly mediates the uptake of the halogenated base analog BrUTP into cultured cells. Although other lipid transfection reagents have been successfully used as vectors for the uptake and incorporation of BrUTP into growing cells (Haukenes et al., 1997; Kanestrom et al., 1998), we demonstrate that lipofection with BrUTP can be a useful tool for studying transport of newly labeled rRNAs in intact cells either within the nucleus or from the nucleus to the cytoplasm.

In summary, this nondestructive method presents several decisive advantages which permits (1) the complementary ultrastructural and optical investigations of the sites in which rRNA elongation and processing take place by using the same labeling conditions; (2) a more 
Optical section
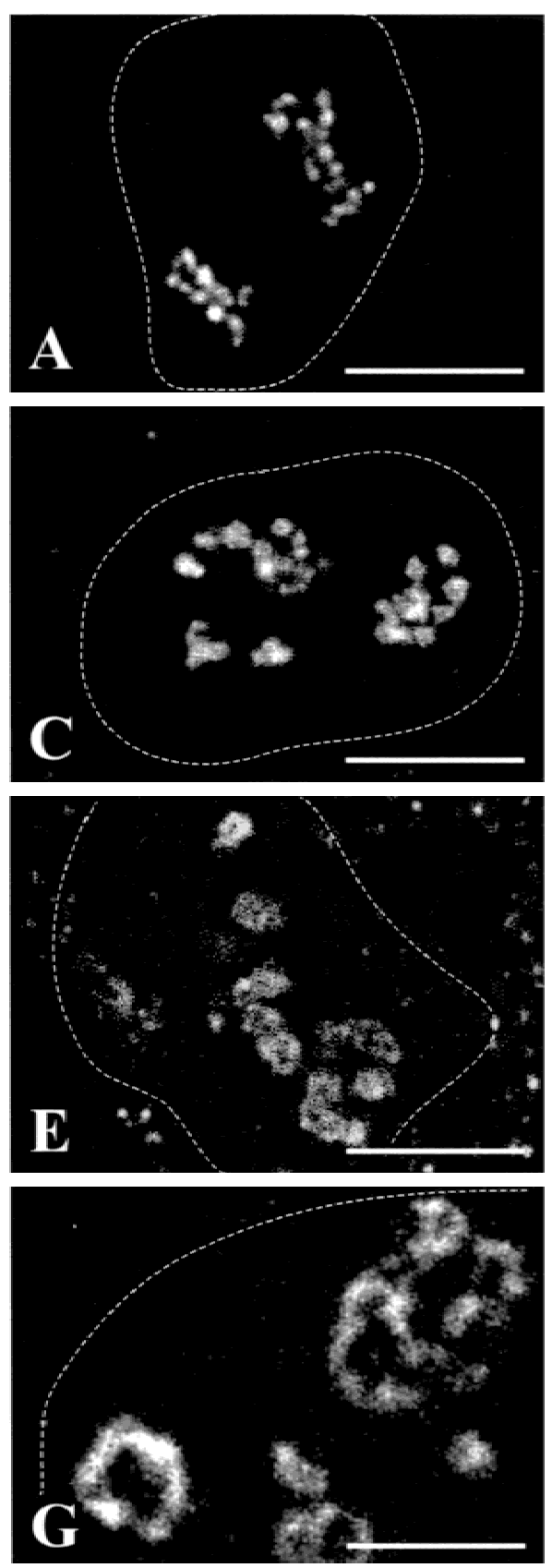

Three -dimensional reconstruction

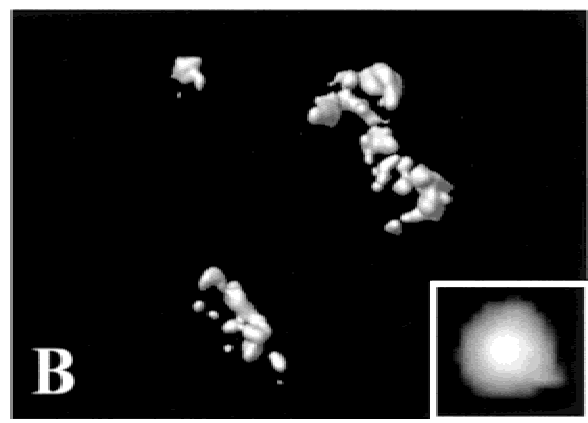

䍐

岂

尽 H

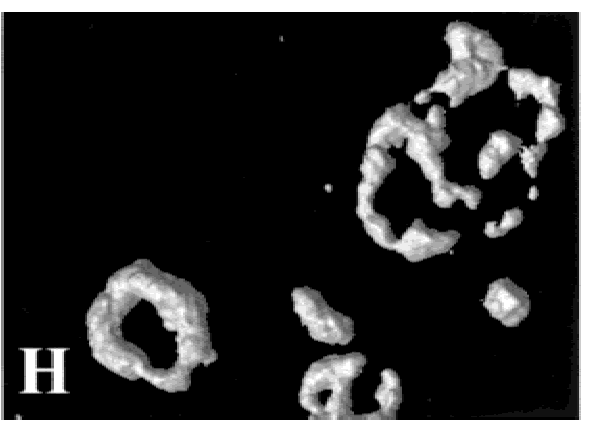

FIGURE 5. Three-dimensional structure of nucleolar subdomains containing the BrUTP-labeled rRNAs during their movement within the nucleolus. $\alpha$-amanitin-treated HeLa cells were lipofected for 15 min with BrUTP-FuGene-6 complexes and then cultured in medium without BrUTP for $2 \mathrm{~min}(\mathbf{A}, \mathbf{B}), 15 \mathrm{~min}(\mathbf{C}, \mathbf{D}), 30 \mathrm{~min}(\mathbf{E}, \mathbf{F})$, and $60 \mathrm{~min}(\mathbf{G}, \mathbf{H})$ before being fixed. BrUTP-labeled rRNAs were detected by an indirect immunofluorescence method. A,C,E,G: Single optical section; B,D,F,H: three-dimensional visualization after three-dimensional reconstruction of the corresponding fields. Insets in $\mathbf{B}$, D, and $\mathbf{F}$ show a higher magnification of three selected areas. Dashed lines indicate the outline of the nucleus. Bar: $5 \mu \mathrm{m}(1 \mu \mathrm{m}$ in insets in $\mathbf{B}$ and $\mathbf{D} ; 2.5 \mu \mathrm{m}$ in inset in $\mathbf{F}$ ).

resolved ultrastructural identification of the nucleolar components containing the BrUTP-labeled RNAs, compared to previous autoradiographic studies (Fakan, 1978, Thiry \& Goessens, 1996); (3) the detailed analy- sis of the volumic organization of the nucleolar components containing the BrUTP-labeled RNAs and of their modification along time by using confocal microscopy, three-dimensional reconstruction, and visualiza- 
tion; (4) the precise identification of BrUTP-RNAs relative to the transcriptional machinery by performing the simultaneous immunodetection of RNA polymerase I molecules.

\section{Volumic organization of rRNA transcription and processing within the nucleolus}

Our ultrastructural data demonstrate that ribosome biogenesis starts in the FC and in the inner part of the DFC, then migrates rapidly in the outer part of the DFC and in the GC. The three-dimensional reconstruction and visualization, by giving a global view, clearly indicate that the transport of rRNAs within the nucleolus occurs neither randomly nor along tracks as for some mRNA (Lawrence et al., 1989; Smith et al., 1999). On the contrary, we demonstrate that transport of rRNA follows a volumic, well-defined pathway from the inner part of the nucleolus toward its periphery. This migration can be summarized by four typical labeling patterns, which could correspond to four main functional domains.

The first pattern consists of several small, plain beads organized as a necklace and located within the nucleoli. The centers of these beads coincide perfectly with the location of RNA polymerase I, whereas their outer part only corresponds to BrUTP. This is confirmed at the ultrastructural level, as RNA polymerase I has been localized exclusively in the FC, whereas we detect BrUTP both in the FC and part of DFC. However, it is difficult to identify transcription sites precisely in vivo (i.e, FC only, central, or more peripheral part of FC), because elongation occurs so rapidly (25-50 nt per second for rRNAs; Grummt, 1978; Hadjiolov, 1985) that even short labeling intervals (1-2 min) are sufficient for full transcripts to travel far away from their synthesis sites (see superimposition of both labelings in Fig. 3C). On the other hand, isolated nucleoli, prepared as described previously (Vandelaer et al., 1996) and pulselabeled for 5 to 15 min with BrUTP, display a labeling not only in the DFC but also indubitably in the FCs (results not shown). Such an in vitro system could be promising to identify the actual sites of rRNA synthesis because, in this case, transcription occurs at a reduced rate. Interestingly, we also show in the present study that all the sites containing RNA polymerase I are simultaneously active for transcription, indicating that no site containing this polymerase is frozen. This observation is consistent with the view that the presence of RNA polymerase I is indicative of its activity, contrary to what was demonstrated for RNA polymerase II transcription (Wei et al., 1999).

The second pattern is characterized by ringlets positioned around unlabeled spheres identified as FCs, as assessed by simultaneous colocalization of BrUTP and RNA polymerase I. Our double labelings further indicate that the ringlets coincide very well with the location of fibrillarin, a marker of the DFC of nucleoli.
Ultrastructural studies confirm that the FCs are free of BrUTP, while the surrounding DFC is strongly labeled. This situation is reminiscent of the localization of U8 SnoRNA, which appears as ringlets around RNA polymerase I and UBF immunolabeled spots (Matera et al., 1994).

The third labeling pattern forms an irregular network constituted with several hollow spheres in which the unlabeled volume corresponds exactly to the beads and ringlets observed for the two previous chasing times. At the ultrastructural level, the labeling is mainly localized in the DFC, at a remote distance from the FC. Consequently, the second and third labeling pattern clearly indicate that in the DFC, the labeling moves from regions immediately surrounding the $\mathrm{FC}$ to areas that are very distant from the FC. From a functional point of view, this finding suggest that the DFC is not a homogeneous component.

It is well established that the pre-rRNA processing occurs in the DFC. Indeed, it has clearly been demonstrated that the DFC is rich in U3SnoRNA (PuvionDutilleul et al., 1991). This RNA catalyzes the initial 5' external transcribed spacer processing and subsequent processing events around the $18 \mathrm{~S}$ region (Kass et al., 1990; Savino \& Gerbi, 1990; Hughes, 1996). Other snoRNAs, such as MRP and U8, which catalyze the processing within internal transcribed spacer $I$ and at the 5.8S and 28S borders, respectively (Peculis \& Steitz, 1993; Schmitt \& Clayton, 1993; Chu et al., 1994), have also been located in the DFC or in a subregion thereof (Reimer et al., 1988; Matera et al., 1994; Jacobson et al., 1995). A fluorescent in situ hybridization analysis (Lazdins et al., 1997), using probes for small selected segments of pre-rRNAs, which have known half-lives, has also revealed that the area of the DFC in which 3' ETS processing takes place is considerably smaller than that in which the $5^{\prime}$ ETS processing occurs. In the light of our present findings, it appears that the DFC could be subdivided into different functional subdomains that correlate with different steps of ribosome biogenesis. First, the DFC directly surrounding FCs appears as an accumulation site, needed for BrUTP-RNA processing following its synthesis within the $\mathrm{FC}$ and its rapid migration from this compartment. Second, the regions of the DFC that are not directly in contact with the FC are three-dimensionally structured as rings centered on the two latter components and functionally correspond to later steps of pre-rRNA processing.

Finally, the fourth labeling pattern, which is mainly located in the GC, appears as huge peripheral rings partially fused together, that surround the previous three other patterns. The breaking of the more peripheral rings could suggest a disassembly of the GC before the spreading of preribosomal particles within the nucleoplasm. The biological relevance of this finding with respect to later steps of rRNA export from the nucleolus toward the cytoplasm remains to be investigated. 
Taken together, these different labeling patterns reveal distinct functional subdomains in which rRNAs are successively passing through. As previously suggested (Lazdins et al., 1997), it is clear that these domains are not strictly superimposed on nucleolar components identified by the presence of given proteins and snoRNAs or identified at the ultrastructural level.

In conclusion, our study demonstrates that BrUTP lipofection followed by immunocytological detection of BrRNAs is a useful tool for high-resolution investigation of the dynamics of RNAs within intact cells. Combined with immunolocalization of proteins involved in different nuclear activities and with highly resolved threedimensional visualizations of the labelings, this method should provide a significant contribution to our understanding of the functional, volumic organization of the cell nucleus.

\section{MATERIALS AND METHODS}

\section{Cell cultures}

HeLa cells were grown at $37^{\circ} \mathrm{C}$ under $5 \% \mathrm{CO}_{2}$ in Glasgow minimum essential medium (Gibco Life Technology, Brussels, Belgium) supplemented with $10 \%$ fetal calf serum. The cells were grown on chambre slides (8-well glass slide, Gibco Life Technology, Paisley, United Kingdom) to 60-80\% monolayer density. To inhibit transcription either by RNA polymerase I or RNA polymerase II, $0.05 \mu \mathrm{g} \mathrm{mL}^{-1}$ actinomycin D (for $1 \mathrm{~h}$ ) or $10 \mu \mathrm{g} \mathrm{mL}^{-1} \alpha$-amanitin (for $2 \mathrm{~h} 30 \mathrm{~min}$ ) were added to some of the slides during preincubation and chasing.

\section{Transfection}

The complexes were prepared extemporaneously: $6 \mu \mathrm{L}$ FuGene- 6 transfection reagent (Roche Diagnostics, Brussels, Belgium) were added directly into $100 \mu \mathrm{L}$ of Glasgow minimum essential medium (Gibco Life Technology). After a 5-min incubation at room temperature, the diluted reagent was added to $5 \mathrm{mM}$ BrUTP (Sigma, Saint Louis, Missouri). The mixture was incubated for a further $15 \mathrm{~min}$ at room temperature. In each well, $150 \mu \mathrm{L}$ of FuGene-6/BrUTP complexes were added to the cells for $15 \mathrm{~min}$ at $37^{\circ} \mathrm{C}$. After this pulse, the complexes were removed and the cells were either directly fixed or incubated for increasing times at $37^{\circ} \mathrm{C}$ in Glasgow minimum essential medium supplemented with $10 \%$ (v/v) fetal calf serum (chase).

\section{Immunofluorescence methods}

The slides were fixed for $10 \mathrm{~min}$ at room temperature in $4 \%$ formaldehyde in $0.1 \mathrm{M}$ PBS ( $\mathrm{pH} 7.4)$. Then, they were permeabilized for $10 \mathrm{~min}$ in $100 \%$ methanol, rehydrated, rinsed in PBS, and further rinsed in PBS containing $1 \%$ BSA (w/v) and normal goat serum (NGS) diluted 1/30. The cells were placed for $30 \mathrm{~min}$ at $37^{\circ} \mathrm{C}$ with a monoclonal anti-BrdU antibody (Roche Diagnostics) diluted 1/100 in PBS, containing NGS diluted $1 / 50$ and $0.2 \%$ BSA. After rinsing with PBS containing $1 \% \mathrm{BSA}$, the slides were incubated for $30 \mathrm{~min}$ at $37^{\circ} \mathrm{C}$ with FITC-conjugated goat anti-mouse antibody (Sigma) diluted $1 / 100$ in PBS containing $0.2 \%$ BSA. After several rinses, the slides were mounted with Citifluor ${ }^{\mathrm{TM}}$ AF1 (Agar Scientific, Starsted, United Kingdom).

For double labeling experiments, the slides were fixed for $5 \mathrm{~min}$ at room temperature in $4 \%$ formaldehyde in $0.1 \mathrm{M}$ PBS $(\mathrm{pH} 7.4)$ containing $1 \%$ Triton $\mathrm{X} 100$. They were rinsed first in PBS, then in PBS containing $1 \%$ BSA, as well as NGS and normal sheep serum (NSS), both diluted $1 / 30$. They were incubated for $30 \mathrm{~min}$ at $37^{\circ} \mathrm{C}$ with an anti-BrdU antibody and a rabbit polyclonal antibody against RNA polymerase I (a gift from Dr. K. Rose, Houston, Texas) or a human autoantibody to fibrillarin (S4; Ochs et al., 1985), both diluted 1/100 in 0.1 M PBS containing $0.2 \%$ BSA, NGS, and NSS, both diluted $1 / 50$. The slides were washed with PBS containing $1 \%$ BSA and incubated for $30 \mathrm{~min}$ at $37^{\circ} \mathrm{C}$ with an FITCconjugated goat anti-mouse antibody (Sigma, for BrUTP) and a biotinylated sheep anti-rabbit antibody (Roche Diagnostics, for RNA Polymerase I) diluted $1 / 100$ in PBS containing $0.2 \%$ BSA. This secondary antibody was detected with streptavidin labeled with Texas Red (Amersham Life Science, Little Chalfont, United Kingdom) diluted $1 / 100$ in PBS containing $0.2 \%$ $\mathrm{BSA}$ for $10 \mathrm{~min}$. After rinsing, the cells were mounted with Citifluor $^{\mathrm{TM}}$ AF1.

\section{Confocal microscopy}

A Biorad 1024ES system (Bio-Rad, Hercules, California) mounted on an inverted IX70 Olympus optical microscope was used. All acquisitions were made using a planapochromat $\times 60,1.4$ numerical aperture oil immersion objective. Acquisitions were performed by exciting the FITC with the 488-nm line of a krypton/argon laser. The emission light was collected through a bandpass filter at $522 \pm 16 \mathrm{~nm}$. Texas Red was excited with the $568-\mathrm{nm}$ line of the same laser. The emission light passed through a high-pass filter at $685 \mathrm{~nm}$ before collecting. Phase contrast images were collected simultaneously on a specific detector. For three-dimensional investigations, 30 to 50 optical sections were recorded with a $0.25-\mu \mathrm{m}$ z-step from the top of the cell. Colocalization of the green and red signals was done in two ways. First, green and red images corresponding to a single optical section were classically overlaid and superimposition of both signals appeared in yellow. Second, a more accurate picture of the colocalization pattern was also obtained by using the Biorad 1024ES software. In this procedure, the intensity in the green channel was plotted against that of the red one for each pixel of both images. The scatter-plot thus obtained was used to select the pixels that display the highest levels of both green and red (i.e., between gray levels 126 and 255). These pixels, which correspond to a significant labeling of both species (i.e., to a real colocalization area) were shown in yellow relative to all the other pixels (that indicated either a single labeling, or a low intensity of at least one of the labelings), which were represented in blue.

\section{Three-dimensional visualizations}

Files were transferred to a Sun Sparc20 workstation (Sun Microsystems, Mountain View, California) for processing, which was performed using the Analyze software (CNSoftware, 
Southwater, United Kingdom)(Héliot et al., 1997; Klein et al., 1998). Volumes were obtained by resampling the number of sections to have an identical pixel size in the $x, y$, and $z$ directions. A $3 \times 3 \times 3$ cubic median filter was subsequently applied to remove background voxels that might have appeared in the final volumic visualization pictures. From the reconstructed volumes, two visualization procedures could be used, both based on ray-tracing methods. On the one hand, the ray passed through the whole volume, and the value of the more intense voxel met through the ray was attributed to the resulting pixel. By scanning all the volume with the ray, a projection was obtained that allowed a volumic visualization. On the other hand, the ray was reflected when it met a voxel that had an intensity superior to a threshold. In contrast to the first method, it led to a surfacic visualization.

\section{Immunoelectron microscopy}

Culture, permeabilization, incorporation, and washings were all carried out in Petri dishes. Cells were fixed for $60 \mathrm{~min}$ at room temperature in a mixture of $4 \%$ formaldehyde and $0.1 \%$ glutaraldehyde in 0.1 M Sörensen's buffer ( $\mathrm{pH} 7.4)$. After fixation, the cells were washed in Sörensen's buffer, dehydrated through graded ethanol solution, and finally embedded in Epikote 812. The resin was polymerized for 2-3 days at 40$45^{\circ} \mathrm{C}$. Ultrathin sections were mounted on nickel, collodioncoated grids. For labeling, the grids were incubated for $30 \mathrm{~min}$ by floating them on a drop of PBS ( $\mathrm{pH} 7.2)$ containing NGS diluted $1 / 30$ and $1 \%$ BSA, then rinsed in PBS containing $1 \%$ BSA. In the next step, the grids were incubated for $4 \mathrm{~h}$ at room temperature with a monoclonal anti-BrdU antibody, diluted 1/100 in PBS ( $\mathrm{pH} 7.2$ ) containing NGS diluted 1/50 and $0.2 \%$ BSA. After washing with PBS ( $\mathrm{pH} 8.2$ ) containing $0.2 \%$ $\mathrm{BSA}$, the grids were incubated at room temperature for $1 \mathrm{~h}$ with goat anti-mouse IgG coupled to 10-nm colloidal gold particles diluted $1 / 40$ in PBS ( $\mathrm{pH} 8.2$ ) containing $0.2 \%$ BSA. Then, they were rinsed in PBS $(\mathrm{pH}$ 8.2) containing $1 \% \mathrm{BSA}$, rinsed in deionized water, and stained with uranyl acetate and lead citrate before examination in a JEOL CX100 II electron microscope at $60 \mathrm{KV}$.

\section{ACKNOWLEDGMENTS}

The authors are grateful to G. Goessens for encouraging discussions and critical reading of the manuscript, to K. Rose for the gift of an anti-RNA polymerase I antibody and to R.L. Ochs for the gift of an anti-fibrillarin antibody. They also acknowledge the skillful technical and secretarial assistance provided by F. Skivée, D. Bourguignon, and S. Bodson. This work received financial support from the "Fonds de la Recherche Scientifique Médicale" (Grant No. 3.4578.98) to M.T., from the "Ligue Régionale de la Marne" from AAERS and from the "Fondation pour la Recherche Médicale" (Grant No. 40001837-01) to D.P., from l'ARC (Grant No. 500642) to T.C. M.T. is a research associate of the National Fund for Scientific Research (Belgium).

Received August 11, 2000; returned for revision September 8, 2000; revised manuscript received September 22, 2000

\section{REFERENCES}

Chu S, Archer R, Zengel J, Lindahl L. 1994. The RNA of RNase MRP is required for normal processing of ribosomal RNA. Proc Natl Acad Sci USA 91:659-663.

Cmarko D, Verschure PJ, Martin TE, Dahmus ME, Krause S, Fu XD, Van Driel R, Fakan S. 1999. Ultrastructural analysis of transcription and splicing in the cell nucleus after bromo-UTP microinjection. Mol Biol Cell 10:211-223.

Daskal Y, Prestayko A, Busch H. 1974. Ultrastructural and biochemical studies of the isolated fibrillar component of nucleoli from Novikoff hepatoma ascites cells. Exp Cell Res 88:1-14.

Dundr M, Raska I. 1993. Non-isotopic ultrastructural mapping of transcription sites within the nucleolus. Exp Cell Res 208:275-281.

Fakan S. 1978. High resolution autoradiography studies on chromatin functions. In: Busch H, ed. The cell nucleus. New York: Academic Press. pp 3-53.

Fay FS, Taneja KL, Shenoy S, Lifshitz L, Singer RH. 1997. Quantitative digital analysis of diffuse and concentrated nucleus distributions of nascent transcripts, SC35 and poly (A). Exp Cell Res 23:27-37.

Grummt I. 1978. In vitro synthesis of pre-rRNAs in isolated nucleoli. In: Busch H, ed. The cell nucleus. New York: Academic Press. pp $373-414$

Hadjiolov A. 1985. The nucleolus and ribosome biogenesis. Cell Biol Monogr 12:1-263.

Haukenes G, Szilvay AM, Brokstad KA, Kanestrom A, Kalland KH. 1997. Labeling of RNA transcripts of eukaryotic cells in culture with $\mathrm{Br}$ UTP using a liposome transfection reagent (DOTAP). BioTechniques 21:308-312.

Héliot L, Kaplan H, Lucas L, Klein C, Beorchia A, Doco-Fenzy M, Ménager M, Thiry M, O'Donohue MF, Ploton D. 1997. Electron tomography of metaphase nucleolar organizer regions: Evidence for a twisted-loop organization. Mol Biol Cell 8:2199-2216.

Hozak P, Cook PR, Schofer C, Mosgoller W, Wachtler F. 1994. Site of transcription of ribosomal RNA and intranucleolar structure in HeLa cells. J Cell Sci 107:639-648.

Hughes J. 1996. Functional base pairing interaction between highly conserved elements of U3 small nucleolar RNA and the small ribosomal subunit. J Mol Biol 259:645-654.

Iborra FJ, Jackson DA, Cook PR. 1998. The path of transcripts from extra-nucleolar synthetic sites to nuclear pores: Transcripts in transit are concentrated in discrete structures containing SR proteins. J Cell Sci 111:2269-2282.

Iborra FJ, Pombo A, Jackson DA, Cook PR. 1996. Active RNA polymerases are localized within discrete transcription "factories" in human nuclei. J Cell Sci 109:1427-1436.

Jackson DA, Hassan AB, Errington RJ, Cook PR. 1993. Visualization of focal sites of transcription within human nuclei. EMBO $J$ 12:1059-1065.

Jacobson MR, Cao LG, Wang YL, Pederson T. 1995. Dynamic localization of RNase MRP RNA in the nucleolus observed by fluorescent RNA cytochemistry in living cells. J Cell Biol 131:16491658.

Kanestrom A, Andresen V, Szilvay AM, Kalland KH, Haukenes G. 1998. Histographic recording of human immunodeficiency virus type 1 (HIV-1) regulatory protein Rev and nuclear factors. Arch Virol 143:279-294.

Kass S, Tyc K, Steitz J, Sollner-Webb B. 1990. The U3 small nucleolar ribonucleoprotein functions in the first step of preribosomal RNA processing. Cell 60:897-908.

Klein C, Cheutin T, O'Donohue MF, Rothblum L, Kaplan H, Beorchia A, Lucas L, Héliot L, Ploton D. 1998. The three-dimensional study of chromosomes and upstream binding factor-immunolabeled nucleolar organizer regions demonstrates their non-random spatial arrangement during mitosis. Mol Biol Cell 9:3147-3159.

Koberna K, Stanek D, Malinsky J, Eltsov M, Pliss A, Ctrnacta V, Cermanova S, Raska I. 1999. Nuclear organization studied with the help of a hypotonic shift: Its use permits hydrophilic molecules to enter into living cells. Chromosoma 108:325-335.

Lamond AI, Earnshaw WC. 1998. Structure and function in the nucleus. Science 280:547-553.

Lawrence JB, Singer R, Marselle L. 1989. Highly localized tracks of specific transcripts within interphase nuclei visualized by in situ hybridization. Cell 57:493-502. 
Lazdins IB, Delannoy M, Sollner-Webb B. 1997. Analysis of nucleolar transcription and processing domains and pre-rRNA movements by in situ hybridization. Chromosoma 105:481-495.

Matera G, Tycowski K, Steitz J, Ward D. 1994. Organization of snoRNPs by fluorescence in situ hybridization and immunocytochemistry. Mol Biol Cell 5:1289-1299.

Masson C, Bouniol C, Fomproix N, Szollos MS, Debey P, HernandezVerdun D. 1996. Conditions favoring RNA polymerase I transcription in permeabilized cells. Exp Cell Res 226:114-125.

Melcak I, Risueno MC, Raska I. 1996. Ultrastructural non-isotopic mapping of nucleolar transcription sites in onion protoplasts. $J$ Struct Biol 116:253-263.

Moss T, Stefanovsky VY. 1995. Promotion and regulation of ribosomal transcription in eukaryotes by RNA polymerase I. Prog Nucleic Acid Res 50:25-66.

Ochs R, Lischwe M, Spohn W, Busch H. 1985. Fibrillarin: A new protein of the nucleolus identified by autoimmune sera. Biol Cell 54:123-134.

Peculis B, Steitz JA. 1993. Disruption of U8 nucleolar snRNA inhibits $5.8 \mathrm{~S}$ and $28 \mathrm{~S}$ rRNA processing in the Xenopus oocyte. Cell 73:1233-1245.

Pombo A, Jackson DA, Hollinshead M, Wang Z, Roeder RG, Cook PR. 1999. Regional specialization in human nuclei visualization of discrete sites of transcription by RNA polymerase III. EMBO J 18:2241-2253.

Puvion-Dutilleul F, Mazan S, Nicoloso M, Christensen ME, Bachellerie JP. 1991. Localization of U3 RNA molecules in nucleoli of HeLa and mouse 3T3 cells by high resolution in situ hybridization. Eur J Cell Biol 56:178-186.

Reimer G, Raska I, Scheer U, Tan E. 1988. Immunolocalization of 7-2 ribonucleoprotein in the granular component of the nucleolus. Exp Cell Res 176:117-128.

Roeder RG. 1976. Eukaryotic nuclear RNA polymerases. In: Losick $\mathrm{R}$, Chamberlin $\mathrm{M}$, eds. RNA polymerase. Cold Spring Harbor, New York: Cold Spring Harbor Laboratory Press. pp 285-329.

Royal A, Simard R. 1975. RNA synthesis in the ultrastructural and biochemical components of the nucleolus of Chinese hamster ovary cells. J Cell Biol 66:577-585.

Savino R, Gerbi SA. 1990. In vivo disruption of Xenopus U3 SnRNA affects ribosomal RNA processing. EMBO J 9:2299-2308.

Scheer U, Hock R. 1999. Structure and function of the nucleolus. Curr Opin Cell Biol 11:385-390.

Scheer U, Rose K. 1984. Localization of RNA polymerase I in inter- phase cells and mitotic chromosomes by light and electron microscopic immunocytochemistry. Proc Natl Acad Sci USA 81: $1431-1435$.

Schmitt M, Clayton D. 1993. Nuclear RNase MRP in required for correct processing of pre-5.8S in Saccharomyces cerevisiae. Mol Cell Biol 13:7935-7941.

Schmittgen TD, Danenberg KD, Horikoshi T, Lentz HJ, Dannenberg PV. 1994. Effects of 5-fluoro- and 5-bromouracil substitution on the translation of human thymidylate synthase mRNA. J Biol Chem 269:16269-16275.

Shaw PJ, Jordan EG. 1995. The nucleolus. Annu Rev Cell Dev Biol 11:93-121.

Sierakowska H, Shuklas RR, Dominski Z, Kole R. 1989. Inhibition of pre-mRNA splicing by 5-fluoro-, 5-chloro- and 5-bromouridine. J Biol Chem 264:19185-19191.

Singer H, Green MR. 1997. Compartmentalization of eukaryotic gene expression: Causes and effects. Cell 91:291-294.

Smith KP, Moen PT Jr, Wydner KL, Coleman JR, Lawrence JB. 1999. Processing of endogenous pre-mRNAs in association with SC-35 domains is gene specific. $J$ Cell Biol 144:617-629.

Sollner-Webb B, Tyc K, Steitz J. 1996. Ribosomal RNA processing in eukaryotes. In: Zimmerman R, Dahlberg A, eds. Ribosomal RNA: Structure, evolution, processing and function in protein synthesis. Boca Raton, Florida: CRC Press. pp 469-490.

Spector DL. 1993. Macromolecular domains within the cell nucleus. Annu Rev Cell Biol 9:265-315.

Strouboulis J, Wolffe AP. 1996. Functional compartmentalization of the nucleus. J Cell Sci 109:1991-2000.

Thiry M, Goessens G. 1996. The nucleolus during the cell cycle. New York: Landes Company, Chapman and Hall RG.

Vandelaer M, Thiry M, Goessens G. 1996. Isolation of nucleoli from ELT cells: A quick new method that preserves morphological integrity and high transcriptional activity. Exp Cell Res 228:125-131.

Wansink DG, Nelissen RL, De Jong L. 1994. In vitro splicing of pre-mRNA containing bromouridine. Mol Biol Rep 19:109-113.

Wansink DG, Schul W, Van Der Kraan I, Van Steensel B, Van Driel R, De Jong L. 1993. Fluorescent labeling of nascent RNA reveals transcription by RNA polymerase II in domains scattered throughout the nucleus. J Cell Biol 122:283-293.

Wei X, Somanathan S, Samarabandu J, Berezney R. 1999. Threedimensional visualization of transcription sites and their association with splicing factor-rich nuclear speckles. J Cell Biol 146:543558. 